\title{
Evaluasi Model Kirkpatrick Pelatihan Persiapan Sertifikasi Penyuluh Antikorupsi pada Pusdiklat PSDM
}

\author{
Khalimi $^{1}$, Pardomuan Robinson Sihombing ${ }^{2}$ \\ ${ }^{1}$ Pusdiklat PSDM, Kemenkeu \\ ${ }^{2}$ Badan Pusat Statistik, Jakarta \\ e-mail: ${ }^{1}$ ayashyhalim@gmail.com, ${ }^{2}$ robinson@bps.go.id

\begin{tabular}{ccc}
\hline Diterima & Direvisi & Disetujui \\
$27-09-2021$ & $01-10-2021$ & $03-10-2021$ \\
\hline
\end{tabular}

\begin{abstract}
Abstrak - Korupsi dapat diartikan sebagai perbuatan yang dilakukan dengan maksud memberikan beberapa keuntungan yang bertentangan dengan tugas dan hak orang lain. Korupsi termasuk kejahatan yang luar biasa, sangat merugikan baik bagi institusi maupun bagi bangsa dan negara. Penelitian ini bertujuan melakukan evaluasi pelatihan persiapan sertifikasi penyuluh antikorupsi pada level 3 dan level 4. Adapun sampel dalam penelitian ini dilakukan di Pusat Pendidikan dan Pelatihan Pengembangan Sumber Daya Manusia Kementerian Keuangan. Pengumpulan data yang digunakan melalui metode wawancara dan pengumpulan angket kuesioner. Alat analisis yang digunakan adalah analisis deskriptif dan analisis inferensia. Analisis inferensia menggunakan uji dua beda sampel berpasangan. Hasil yang didapat pelaksanaan pelatihan persiapan sertifikasi penyuluh antikorupsi memberikan perubahan perilaku peserta di tempat kerja. Hal ini dinyatakan dalam hasil survey ditunjukkan dengan hasil rata-rata setelah pelatihan meningkatkan dari sebelum pelatihan. Hal ini diperkuat dengan hasil uji beda baik untuk level 3 maupun level 4 yang signifikan. Dari hasil wawancara diperoleh bahwa alumni dalam tugasnya sehari-hari di kantor juga telah menerapkan nilai-nilai dasar antikorupsi. Perilaku ini dapat menguatkan posisi alumni yang baik.
\end{abstract}

Kata Kunci : antikorupsi, pelatihan dan penyuluhan, uji beda

Abstract - Corruption can be interpreted as an act carried out with the intention of providing some advantage that is contrary to the duties and rights of others. Corruption is an extraordinary crime, very detrimental to both institutions and the nation and state. This study aims to evaluate the preparation of training for anti-corruption instructor certification at level 3 and level 4. The sample in this study was conducted at the Center for Human Resource Development Education and Training, Ministry of Finance. The data collection used was through the interview method and the collection of questionnaires. The analytical tools used are descriptive analysis and inferential analysis. Inferential analysis using two different paired sample tests. The results obtained from the implementation of the anti-corruption instructor certification preparation training provided a change in participants' behavior in the workplace. This is stated in the survey results indicated by the average results after training increasing from before training. This is reinforced by the different test results for both level 3 and level 4 which are significant. From the results of the interview, it was found that alumni in their daily duties in the office have also implemented basic anti-corruption values. This behavior can strengthen a good alumni position.

Keywords: anti-corruption; different test; training and counseling

\section{PENDAHULUAN}

Kementerian Keuangan (Kemenkeu) telah melakukan Reformasi Birokrasi sejak tahun 2002. Berdasarkan hasil Evaluasi Akuntabilitas Kinerja tahun 2015 yang dilakukan oleh Kementerian PAN$\mathrm{RB}$, Kemenkeu berhasil meraih nilai tertinggi dengan predikat memuaskan dari 86 Kementerian/Lembaga $(\mathrm{K} / \mathrm{L})$ yang dievaluasi. Dalam hal kinerja integritas organisasi, Kemenkeu juga patut berbangga dengan hasil laporan Survei Penilaian Integritas Tahun 2017 yang dilakukan oleh Komisi Pemberantasan Korupsi (KPK) yang menempatkan Kemenkeu sebagai K/L dengan Indeks Persepsi Integritas tertinggi di Indonesia (KPK, 2017). Demikian juga dengan penerapan sistem integritas di instansi pemerintah, melalui pembangunan Zona Integritas menuju Wilayah Bebas dari Korupsi (WBK) dan Wilayah Birokrasi Bersih dan Melayani (WBBM), Kemenkeu menjadi $\mathrm{K} / \mathrm{L}$ yang memiliki instansi vertikal yang mendapatkan penilaian WBK/WBBM terbanyak, yaitu 1 instansi dengan predikat WBBM dan 59 instansi mendapat predikat WBK (Kemenpan RB, 2018).

Meskipun demikian, berdasarkan hasil laporan Survei Penilaian Integritas (SPI) secara internal, terdapat beberapa hal yang perlu mendapat perhatian, antara lain masih adanya persepsi yang menurun terhadap budaya integritas Kemenkeu (Kementerian Keuangan, 2018). Di samping itu, fakta 
di lapangan masih ditemukan adanya praktik korupsi dengan bukti masih terjadinya kasus Operasi Tangkap Tangan (OTT) yang dilakukan KPK dan ditemukannya praktik perilaku koruptif dan penyalahgunaan wewenang oleh pejabat/pegawai di lingkungan Kemenkeu. Perilaku mereka tidak hanya merugikan organisasi Kemenkeu, tetapi juga menurunkan kepercayaan masyarakat dalam pengelolaan keuangan negara. Kasus korupsi seperti ini telah merusak sendi budaya integritas Kemenkeu, mencoreng nama baik dan tidak sedikit menghancurkan kepercayaan masyarakat atas nilainilai integritas yang telah dimiliki dana dibangun bersama oleh seluruh pimpinan dan pegawai Kemenkeu.

Berdasarkan indikasi-indikasi di atas, Kemenkeu kemudian menggulirkan program Penguatan Budaya Kementerian Keuangan berupa: pertama, Kode Etik dan Kode Perilaku Kemenkeu (Penetapan PMK Kode Etik dan Kode Perilaku pegawai); kedua, Culture Assessment (survey penilaian kondisi budaya Kementerian Keuangan); ketiga, Duta Transformasi dan Light House (Penunjukan Pejabat Eselon III sebagai Duta Tansformasi yang dibantu oleh Lighthouse Team); keempat, Leadership Role Model (vlog para pimpinan pejabat eselon I); kelima, Gerakan Efisiensi Kemenkeu (KMK-346/IMK.01/2017 Gerakan Efisiensi sebagai Penguatan Budaya Kementerian Keuangan); keenam, Internalisasi Budaya organisasi (Workshop Duta Transformasi, Festival Budaya Kemenkeu); ketujuh, Integrity Framework (Penyusunan Integrity Framework sebagai Better Practice Guide Kemenkeu); kedelapan, Penyuluh Antikorupsi bersertifikasi (Pelatihan dan Sertifikasi Penyuluh Antikorupsi).

Dalam rangka penguatan Program Penguatan Budaya dan Nilai-Nilai Kementerian Keuangan, Kemenkeu menyelenggarakan Pelatihan Persiapan Sertifikasi Penyuluh Antikorupsi yang bertujuan untuk mempersiapkan Penyuluh Antikorupsi yang dapat berperan dalam upaya meningkatkan integritas organisasi dengan mengikuti proses Sertifikasi Penyuluh Antikorupsi Jenjang Pratama melalui jalur pelatihan/Diklat. Pelatihan Persiapan Sertifikasi Penyuluh Antikorupsi Kementerian Keuangan, terselenggara atas kerja sama Central Transformation Office (CTO) Sekretaris Jenderal Kementerian Keuangan, Pusdiklat Pengembangan Sumber Daya Manusia (Badan Pendidikan dan Pelatihan Keuangan) dan Deputi Bidang Pencegahan Komisi Pemberantasan Korupsi (Pusat Edukasi Antikorupsi/ACLC dan Lembaga Sertifikasi Profesi (LSP) KPK. Penyelenggaraan pelatihan dan sertifikasi penyuluh antikorupsi dilaksanakan oleh dua instansi yang berbeda, yakni Pelatihan Persiapan Sertifikasi Penyuluh Antikorupsi di Pusdiklat Pengembangan Sumber Daya Manusia dan kegiatan Sertifikasi dalam bentuk assessment dilaksanakan oleh PKN STAN.

Pelatihan Persiapan Sertifikasi Penyuluh Antikorupsi tahun 2019 diselenggarakan dalam 30 angkatan dengan jumlah peserta 860 pegawai yang berasal dari seluruh unit eselon I di lingkungan Kemenkeu. Dari total jumlah 860 peserta, 37 peserta dinyatakan tidak lulus dan 823 peserta dinyatakan lulus pelatihan dan direkomendasikan mengikuti proses assesment menjadi Penyuluh Antikorupsi di TUK Kementerian Keuangan PKN STAN. Anggaran pelatihan dibebankan pada DIPA Pusdiklat Pengembangan Sumber Daya Manusia tahun 2019 dengan total anggaran yang dikeluarkan sebesar Rp 1.336.615.824.

Mengingat bahwa program pelatihan ini memiliki peranan yang sangat strategis dan menggunakan anggaran negara yang besar (Atmodiwirio, 2005). Sehingga dipandang perlu untuk melakukan suatu kajian atau penelitian untuk menjamin kualitas pelatihan dan menjawab kebutuhan organisasi terkait peningkatan integritas organisasi dengan melaksanakan evaluasi baik pada saat proses pelatihan berlangsung, maupun hingga pelatihan telah selesai dan para alumni telah kembali di unit kerja masing-masing.

Sebagai unit pelaksana pendidikan dan pelatihan di lingkungan Kementerian Keuangan, Badan Pendidikan dan Pelatihan Keuangan (BPPK) senantiasa berkomitmen untuk senantiasa menjaga dan meningkatkan kualitas pembelajaran (diklat) yang diselenggarakan untuk mewujudkan pelayanan prima. Komitmen menjaga kualitas pembelajaran di BPPK dilakukan mulai dari perencanaan pembelajaran sampai pada evaluasi pascapembelajaran. Perencanaan pembelajaran dilakukan dengan melakukan Analisis Kebutuhan Pembelajaran (AKP) dan menyusun Desain Pembelajaran serta validasi program Pembelajaran secara intensif (Arsyad, 2015). Kualitas penyelenggaraan pembelajaran dilakukan dengan senantiasa memantau atau mengevaluasi kualitas pembelajaran berdasarkan survei kepada peserta selama pembelajaran berlangsung. Tahap terakhir adalah evaluasi pascapembelajaran (pascapelatihan) yang bertujuan untuk mengetahui apakah pembelajaran yang diikuti mampu memberikan kontribusi terhadap peningkatan kinerja alumni peserta dan/atau kinerja organisasi.

BPPK menggunakan evaluasi model Kirkpatrick (Kirkpatrick, 2006) dalam melaksanakan evaluasi terhadap pendidikan dan pelatihan (diklat). Evaluasi model ini terdiri dari 4 level, dimana setiap level dalam model evaluasi ini mempengaruhi level berikutnya. Keempat level evaluasi itu adalah (1) Level 1 (Reaction), yaitu evaluasi pada yang mengukur bagaimana peserta bereaksi terhadap diklat yang diikuti, atau dengan kata lain mengukur kepuasan peserta pembelajaran (customer satisfaction); (2) Level 2 (Learning), yaitu evaluasi yang mengukur proses belajar dalam diklat yakni terjadinya transfer pengetahuan (transfer of learning). Evaluasi pada level ini bertujuan untuk mengukur hasil belajar peserta, yang antara lain perubahan sikap, berkembangnya pengetahuan dan/atau peningkatan keterampilan; (3) Level 3 (Behavior), yaitu evaluasi yang bertujuan untuk mengetahui sejauh mana perubahan perilaku terjadi 
setelah peserta mengikuti diklat; dan (4) Level 4 (Results), yaitu evaluasi untuk mengukur result atau hasil akhir yang terjadi setelah peserta mengikuti diklat. Hasil akhir tersebut dapat berupa peningkatan produktivitas atau kinerja, peningkatan kualitas, penurunan biaya, penurunan tingkat kecelakaan kerja, peningkatan penjualan, penurunan tingkat keluar masuk pegawai, dan meningkatnya keuntungan.

Atas pelaksanaan Pelatihan Persiapan Sertifikasi Penyuluh Antikorupsi, telah dilakukan evaluasi penyelenggaraan yang dilaksanakan oleh Pusdiklat Pengembangan Sumber Daya Manusia dengan hasil evaluasi sangat baik, dan Evaluasi Pembelajaran Pelatihan pada aspek Materi, Metode dan Media Pembelajaran oleh penulis dengan hasil secara umum dinilai telah memenuhi kebutuhan peserta. Kedua bentuk evaluasi ini merupakan bentuk evaluasi Level 1 dan evaluasi Level 2 yang dilakukan pada saat proses pelatihan berlangsung dalam bentuk Performance Test oleh Tim Fasilitator. Sedangkan evaluasi Level 3 dan Level 4 terhadap program pelatihan, belum dilakukan.

Oleh karena itu, pada kajian atau penelitian ini, penulis melakukan evaluasi Level 3 dan Level 4 berdasarkan evaluasi model Kirkpatrick dengan judul "Evaluasi Model Kirkpatrick Level 3 dan 4 pada Pelatihan Persiapan Sertifikasi Penyuluh Antikorupsi di Pusat Pendidikan dan Pelatihan Pengembangan Sumber Daya Manusia”.

\section{METODE PENELITIAN}

Penelitian ini menggunakan pendekatan mixed method yaitu menggunakan analisis penelitian kuantitatif dan kualitatif yang bersifat obyektif berdasarkan fakta, data dan teori ilmiah (Cresswell, 2010). Metode penelitian kombinasi (mixed method) adalah suatu metode penelitian yang mengkombinasikan atau menggabungkan antara metode kuantitatif dan metode kualitatif yang digunakan secara bersama-sama dalam suatu kegiatan penelitian sehingga diperoleh data yang lebih komprehensif, valid, reliabel dan obyektif (Arikunto, 2010).

Populasi dalam penelitian adalah seluruh peserta pada 30 angkatan pelatihan sebanyak 863 peserta. Teknik pemilihan sampel yang digunakan adalah purposive sampling, yaitu teknik pengambilan sampel yang dibatasi hanya pada orang-orang tertentu yang dapat memberikan informasi yang diinginkan, atau karena mereka memenuhi beberapa kriteria yang telah ditetapkan oleh peneliti (Sekaran, 2006). Sampel penelitian ini dipilih dengan kriteria bahwa peserta pada angkatan pelatihan berasal dari berabgai unit eselon I di lingkungan Kementerian Keuangan, saat mengikuti pelatihan peserta bekerja di unit kepatuhan internal dan atau di unit teknis lainnya. Berdasarkan kriteria tersebut, peneliti memilih alumni angkatan XXIX dan XXX. Formulir kuesioner disebar kepada 51 orang alumni pada Angkatan XXIX dan XXX. Kemudian sampel yang dipilih adalah sebanyak 27 orang yaitu peserta yang mengembalikan kuesioner kepada peneliti.

Tabel 1. Operasional Variabel Penelitian

\begin{tabular}{|c|c|c|}
\hline Variabe & $\begin{array}{c}\text { Level } 3 \\
\text { (Behavior) }\end{array}$ & $\begin{array}{c}\text { Level } 4 \\
\text { (Results) }\end{array}$ \\
\hline Definisi & $\begin{array}{lr}\text { Implementasi } & \text { hasil } \\
\text { pelatihan PAKSI dalam } \\
\text { meningkatkan } \\
\text { kompetensi } \\
\text { pelatihan alumni } \\
\text { mendukung pekerjaan } \\
\text { alumni setelah kembali } \\
\text { ke unit kerja }\end{array}$ & $\begin{array}{l}\text { Implementasi } \\
\text { hasil pelatihan } \\
\text { yang } \\
\text { berdampak } \\
\text { kepada } \\
\text { peningkatan } \\
\text { kinerja } \\
\text { organisasi }\end{array}$ \\
\hline Indikator & 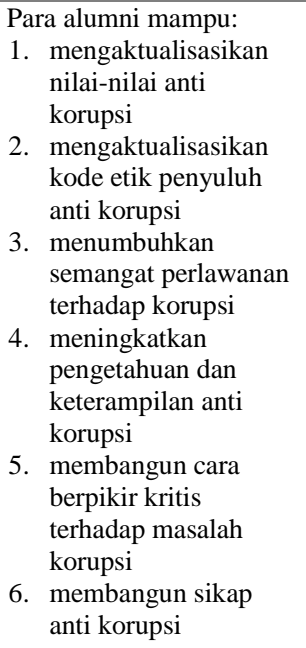 & $\begin{array}{l}\text { Menganalisis } \\
\text { hasil } \\
\text { rekapitulasi dan } \\
\text { pengolahan data } \\
\text { kuesioner dan } \\
\text { wawancara }\end{array}$ \\
\hline $\begin{array}{l}\text { Implementasi } \\
\text { hasil } \\
\text { pelatihan } \\
\text { yang } \\
\text { berdampak } \\
\text { kepada } \\
\text { peningkatan } \\
\text { kinerja } \\
\text { organisasi }\end{array}$ & $\begin{array}{l}\begin{array}{l}\text { Para alumni mampu } \\
\text { berperan dalam }\end{array} \\
\text { mendukung perilaku anti } \\
\text { korupsi di organisasi. }\end{array}$ & $\begin{array}{l}\text { Menganalisis } \\
\text { hasil } \\
\text { rekapitulasi data } \\
\text { wawancara. }\end{array}$ \\
\hline
\end{tabular}

Sumber: Widojoko (2009) dan Wexley \& Lataham (1991)

\section{HASIL DAN PEMBAHASAN}

Uji validitas dan reliabilitas instrumen dilakukan terhadap kuesioner yang disebarkan kepada 51 orang alumni pelatihan. Pengujian dilakukan terhadap 20 butir pernyataan pada kuesioner untuk mengukur Level 3 dan 8 butir pernyataan pada kuesioner untuk mengukur Level 4.

Pengujian realibilitas dengan metode Cronbach Alpha juga dilakukan terhadap 20 butir pernyataan pada kuesioner untuk mengukur Level 3 dan 8 butir pernyataan pada kuesioner untuk mengukur Level 4.

Tabel 2. Uji Reabilitas

\begin{tabular}{|ccc|c|c|}
\hline \multirow{2}{*}{ Kuesioner } & \multicolumn{2}{c|}{$\begin{array}{c}\text { Reliability Statistics } \\
\text { (Sebelum) }\end{array}$} & \multicolumn{2}{c|}{$\begin{array}{c}\text { Reliability Statistics } \\
\text { (Setelah) }\end{array}$} \\
\cline { 2 - 5 } & $\begin{array}{c}\text { Cronbach's } \\
\text { Alpha }\end{array}$ & $\begin{array}{c}\text { N of } \\
\text { Items }\end{array}$ & $\begin{array}{c}\text { Cronbach's } \\
\text { Alpha }\end{array}$ & $\begin{array}{c}\text { N of } \\
\text { Items }\end{array}$ \\
\hline Level 3 & 0.968 & 20 & 0.983 & 20 \\
Level 4 & 0.958 & 8 & 0.955 & 8 \\
\hline
\end{tabular}


Berdasarkan Tabel 2 di atas, dengan membandingkan nilai Cronbach Alpha instrumen penelitian dengan nilai kriteria realibilitas sebagaimana yang disebutkan oleh Triton (2005), maka dapat dinyatakan bahwa instrumen penelitian adalah sangat reliable dengan nilai Cronbach Alpha yang melebihi nilai ambang batas. Hal ini berarti semua butir pernyataan mempunyai kehandalan/konsistensi yang dapat dipertanggungjawabkan (reliabel).

Pengujian valditas dilakukan dengandengan metode Correlated Item-Total Correlation. Hasil pengujian diperoleh sebagaimana Tabel 3. berikut:

\begin{tabular}{|c|c|c|}
\hline Item Pertanyaan & $\begin{array}{l}\text { Corrected Item- } \\
\text { Total Correlation } \\
\text { (Sebelum) }\end{array}$ & $\begin{array}{c}\text { Corrected Item- } \\
\text { Total Correlation } \\
\text { (Setelah) }\end{array}$ \\
\hline 1 & $.755^{* * *}$ & $.755^{* *}$ \\
\hline 2 & $.756 * *$ & $.756^{* * *}$ \\
\hline 3 & $.839 * *$ & $.839 * *$ \\
\hline 4 & $.900 * *$ & $.900 * *$ \\
\hline 5 & $.911 * *$ & $.911 * *$ \\
\hline 6 & $.704 * *$ & $.704 * *$ \\
\hline 7 & $.729 * *$ & $.729 * *$ \\
\hline 8 & $.928 * *$ & $.928 * *$ \\
\hline 9 & $.915^{* *} *$ & $.915 * *$ \\
\hline 10 & $.927 * *$ & $.927 * *$ \\
\hline 11 & $.902 * *$ & $.902 * *$ \\
\hline 12 & $.914 * *$ & $.914 * *$ \\
\hline 13 & $.920 * *$ & $.920 * *$ \\
\hline 14 & $.883^{* *} *$ & $.883 * *$ \\
\hline 15 & $.937 * *$ & $.937 * *$ \\
\hline 16 & $.945 * *$ & $.945 * *$ \\
\hline 17 & $.827 * *$ & $.827 * *$ \\
\hline 18 & $.924 * *$ & $.924 * *$ \\
\hline 19 & $.909 * *$ & $.909 * *$ \\
\hline 20 & $.875^{* *} *$ & $.875^{* *} *$ \\
\hline Item Pertanyaan & $\begin{array}{c}\text { Corrected Item- } \\
\text { Total Correlation } \\
\text { (Sebelum) }\end{array}$ & $\begin{array}{c}\text { Corrected Item- } \\
\text { Total Correlation } \\
\text { (Setelah) }\end{array}$ \\
\hline 1 & $.960 * *$ & $.960 * *$ \\
\hline 2 & $.896 * *$ & $.912 * *$ \\
\hline 3 & $.832 * *$ & $.838 * *$ \\
\hline 4 & $.809^{* *} *$ & $.885 * *$ \\
\hline 5 & $.890 * *$ & $.862 * *$ \\
\hline 6 & $.928 * *$ & $.880 * *$ \\
\hline 7 & $.868 * *$ & $.844 * *$ \\
\hline 8 & $.881 * *$ & $.917 * *$ \\
\hline
\end{tabular}

Berdasarkan Tabel 3 di atas, dengan membandingkan masing-masing nilai r-hitung (Correlation Item-Total Correlation) pada setiap item pertanyaan berdasarkan tabel di atas dengan rtabel untuk degree of freedom $(\mathrm{df})=\mathrm{N}-2=$ dan alpha $5 \%$, di mana r-tabel untuk kuesioner alumni=0,3809, maka dapat dinyatakan bahwa semua nilai r-hitung masing-masing pertanyaan yang digunakan sebagai instrumen untuk mengukur variabel penelitian pada kuesioner adalah lebih besar dari nilai r-tabel. Sehingga dapat dinyatakan bahwa seluruh item pertanyaan pada instrumen penelitian (kuesioner) adalah valid.

\section{Penempatan Tugas dan Transfer Learning}

Hasil rekapitulasi data kuesioner terhadap penempatan tugas dan transfer learning oleh alumni pelatihan sebagaimana para Tabel 4 berikut:

Tabel 4. Statistik Persepsi Alumni Terhadap Penempatan Tugas dan Transfer Learning

\begin{tabular}{|c|c|c|c|}
\hline \multirow[t]{2}{*}{ Pertanyaan } & \multicolumn{3}{|c|}{ Jawaban } \\
\hline & $\mathrm{Ya}$ & Tidak & Jumlah \\
\hline \multirow[t]{2}{*}{$\begin{array}{l}\text { Apakah saat ini Anda masih } \\
\text { melakukan pekerjaan di unit } \\
\text { kepatuhan internal atau } \\
\text { bagian yang berkaitan } \\
\text { dengan integritas organisasi? }\end{array}$} & $\begin{array}{c}15 \\
(55,6 \%)\end{array}$ & $\begin{array}{c}12 \\
(44,4 \%)\end{array}$ & $\begin{array}{c}27 \\
(100 \%)\end{array}$ \\
\hline & Sudah & Belum & Jumlah \\
\hline $\begin{array}{l}\text { Apakah Anda sudah } \\
\text { melakukan praktik } \\
\text { penyuluhan sesuai dengan } \\
\text { standar kompetensi yang } \\
\text { dipersyaratkan dalam } \\
\text { SKKNI Penyuluh } \\
\text { Antikorupsi kepada rekan } \\
\text { kerja atau pegawai lainnya } \\
\text { di tempat kerja Anda? }\end{array}$ & $\begin{array}{c}22 \\
(81,5 \%)\end{array}$ & $\begin{array}{c}5 \\
(18,5 \%)\end{array}$ & $\begin{array}{c}27 \\
(100 \%)\end{array}$ \\
\hline \multicolumn{2}{|c|}{$\begin{array}{c}\text { Penugasan/kebutuhan } \\
\text { organisasi }\end{array}$} & $\begin{array}{c}\text { Inisiatif } \\
\text { saya } \\
\text { sendiri } \\
\end{array}$ & Jumlah \\
\hline $\begin{array}{l}\text { Mengapa } \\
\text { Anda } \\
\text { mengikuti } \\
\text { pelatihan } \\
\text { ini? }\end{array}$ & & $\begin{array}{c}6 \\
(22,2 \%)\end{array}$ & $\begin{array}{c}27 \\
(100 \%)\end{array}$ \\
\hline
\end{tabular}

Berdasarkan Tabel 4 di atas, terlihat bahwa mayoritas responden $(55,6 \%)$ saat ini sedang ditugaskan atau ditempatkan pada bagian yang masih melakukan pekerjaan di unit kepatuhan internal atau bagian yang berkaitan dengan penegakan integritas organisasi. Sebagian besar di antara responden $(81,5 \%)$ juga sudah melakukan praktik penyuluhan sesuai dengan standar kompetensi yang dipersyaratkan dalam SKKNI Penyuluh Antikorupsi kepada rekan kerja atau pegawai lainnya di tempat kerja. Selain itu, $77,8 \%$ responden mengikuti pelatihan ini karena adanya penugasan/kebutuhan organisasi. Dari statistik ini, dapat dinyatakan bahwa evaluasi untuk mengetahui sejauh mana Program Pelatihan Persiapan Sertifikasi Penyuluh Antikorupsi memberikan kontribusi bagi perubahan perilaku peserta dan peningkatan integritas organisasi di enam (6) Unit Eselon I yang telah mengirimkan pegawainya mengikuti pelatihan ini, menjadi sangat relevan untuk dilakukan.

Tabel 5. Statistik Deksriptif Perubahan Kompetensi

\begin{tabular}{ccc}
\hline \multicolumn{3}{c}{ Level 3 } \\
\hline $\begin{array}{c}\text { Pertanyaan } \\
\text { (Kompetensi) }\end{array}$ & \multicolumn{2}{c}{ Mean (rata-rata) } \\
\cline { 2 - 3 } & Sebelum & Sesudah \\
\hline 1 & 3.93 & 4.56 \\
\hline 2 & 3.96 & 4.70 \\
\hline 3 & 3.74 & 4.52 \\
\hline 4 & 3.70 & 4.56 \\
\hline 5 & 3.67 & 4.22 \\
\hline 6 & 3.07 & 4.37 \\
\hline 7 & 2.96 & 4.37 \\
\hline 8 & 3.30 & 4.44 \\
\hline 9 & 3.44 & 4.52 \\
\hline
\end{tabular}




\begin{tabular}{ccc}
\hline 10 & 3.33 & 4.48 \\
\hline 11 & 3.37 & 4.52 \\
\hline 12 & 3.33 & 4.48 \\
\hline 13 & 3.26 & 4.44 \\
\hline 14 & 3.00 & 4.15 \\
\hline 15 & 2.81 & 4.26 \\
\hline 16 & 2.70 & 4.22 \\
\hline 17 & 2.56 & 4.19 \\
\hline 18 & 2.70 & 4.26 \\
\hline 19 & 2.48 & 4.19 \\
\hline 20 & 2.48 & 4.22 \\
\hline Mean (rata-rata) & 3.19 & 4.38 \\
\hline
\end{tabular}

Berdasarkan Tabel 5 di atas secara simultan untuk Level 3 terjadi peningkatan rata-rata nilai sebelum dan sesudah dimana nilai rata-rata sebelum 3.19 dan meningkat menjadi 4.38. Begitu juga secara parsial untuk masing-masing pertanyaan terjadi peningkatan nilai rata-ratanya.

Tabel 6. Statistik Deksriptif Perubahan Dampak

\begin{tabular}{ccc}
\hline & \multicolumn{2}{c}{ Level 4 } \\
\cline { 2 - 3 } Pertanyaan & \multicolumn{2}{c}{ Mean (rata-rata) } \\
\cline { 2 - 3 } (Kompetensi) & Sebelum & Sesudah \\
\hline 1 & 3.52 & 4.41 \\
\hline 2 & 3.78 & 4.56 \\
\hline 3 & 3.70 & 4.48 \\
\hline 4 & 3.78 & 4.63 \\
\hline 5 & 3.37 & 4.30 \\
\hline 6 & 3.48 & 4.44 \\
\hline 7 & 3.22 & 4.19 \\
\hline 8 & 3.41 & 4.30 \\
\hline Mean (rata-rata) & 3.53 & 4.41 \\
\hline
\end{tabular}

Berdasarkan Tabel 6 di atas secara simultan untuk Level 5 terjadi peningkatan rata-rata nilai sebelum dan sesudah dimana nilai rata-rata sebelum 3.53 dan meningkat menjadi 4.41. Begitu juga secara parsial untuk masing-masing pertanyaan terjadi peningkatan nilai rata-ratanya.

Hasil analisis uji t berpasangan (t-paired) data kuesioner yang dibagikan kepada responden untuk membandingkan adakah perbedaan mean atau rata-rata sebelum dan sesudah pelatihan dalam meningkatkan kompetensi para alumni adalah sebagai berikut:

Tabel 7. Uji Beda Dua Sampel Berpasangan

\begin{tabular}{lrrrrr}
\hline $\begin{array}{l}\text { Paired Differences } \\
\text { (Sebelum-Sesuda) }\end{array}$ & Mean & $\begin{array}{l}\text { Std. } \\
\text { Error } \\
\text { Mean }\end{array}$ & t & df & Sig. \\
\hline level 3 & -23.5 & 1.85 & -12.7 & 26 & 0 \\
\hline level 4 & -7.03 & 0.83 & -8.4 & 26 & 0
\end{tabular}

Dari hasil Tabel 7, dapat dinyatakan bahwa para alumni memiliki persepsi bahwa program pelatihan yang dilakukan berhasil dan memiliki pengaruh yang signifikan dalam peningkatan kompetensi alumni, dengan adanya perbedaan (peningkatan) nilai rata-rata sebelum dan sesudah program pelatihan. Hasil yang sama antara level 3 dan level 4. Hasil ini senada dengan penelitian Azwar (2019) dan Detty (2009), dimana terjadi peningkatan nilai setelah adanya pelatihan.

\section{Pembahasan}

Jika dilihat perubahan perilaku - evaluasi Kirkpatrick Level 3, pada Tabel 6 mengindikasikan bahwa secara rata-rata terjadi perubahan perilaku alumni meningkat yang ditunjukkan dengan hasil rata-rata sebelum pelatihan adalah 3,53 dan hasil ratarata setelah pelatihan adalah 4,41. Peningkatan perubahan perilaku ini dapat terjadi mengingat lingkungan pekerjaan yang dihadapi sehari-hari menuntut tanggung jawab dan perilaku integritas yang tinggi.

Alumni pelatihan yang masih bekerja di bagian Kepatuhan Internal berdasarkan hasil survey dalam tabel 4.4 adalah $55,6 \%$ dan yang sudah mutasi ke bagian lain sebanyak 44,4\%. Gap hasil antara yang masih bekerja di bagian Kepatuhan Internal dan yang sudah dimutasikan ke bagian teknis atau lainnya tidak terlalu besar perbedaannya. Dari hasil jawaban yang diperoleh diketahui bahwa alumni meskipun dipindahkan ke bagian lain, yaitu bagian teknis pada satuan kerja, diindikasikan bahwa para alumni tetap berperilaku menerapkan pengetahuan yang diperoleh terkait dengan nilai-nilai antikorupsi yang menjadi penguatan nilai integritas di lingkungan kerjanya.

Perubahan peningkatan perilaku yang ada pada alumni juga dikarenakan adanya peningkatan kompetensi alumni dalam bekerja. Hal ini ditunjukkan dengan hasil pada Tabel 4. Peningkatan kompetensi ini juga diperkuat dengan bahwa sebagian besar alumni bekerja pada bagian Kepatuhan Internal di unit kerjanya. Tusi pejabat di bagian Kepatuhan Internal berhubungan erat dengan pembimbingan dan pengawasan integritas pegawai. Materi pelatihan penyuluh anti korupsi sangat berkaitan dengan aktivitas yang ada di bagian Kepatuhan Internal.

Dari hasil wawancara diperoleh bahwa alumni dalam tugasnya sehari-hari di kantor juga telah menerapkan nilai-nilai dasar antikorupsi yaitu disiplin, tanggungjawab, dan adil. Perilaku disiplin yang dilakukan oleh alumni di kantor terkait dengan tusi yang melekat pada jabatan yang diemban. Perilaku ini dapat menguatkan posisi alumni sebagai Kasuki. Sebagai Kasuki alumni mendapat amanah untuk membimbing dan memantau pegawai dalam kedisiplinan dan integritas.

Sebagaimana disebutkan dalam pernyataan yang ada dalam kuesioner yaitu alumni memiliki pengalaman menyampaikan kebenaran dalam situasi yang sulit dan berisiko dan pernyataan bahwa alumni pernah menegur orang lain karena yang bersangkutan melanggar nilai-nilai dan norma yang berlaku.

Keikutsertaan pegawai dalam pelatihan ini sesuai data pada tabel 4.4, sebanyak 77,8\% menyatakan karena ditugaskan oleh instansi. Yang memang ingin mengikuti pelatihan hanya $22,2 \%$. Secara data dapat diperoleh bahwa mengikuti pelatihan ini bukan karena keinginan pegawai tersebut. Dampak dari ini terlihat hampir 50\% peserta tidak berkenan untuk melanjutkan sampai ke jenjang sertifikasi. Hasil ini kami peroleh pada saat akhir 
pelatihan, peserta diminta untuk mengisi survey terkait keinginan untuk melanjutkan ke tahap sertifikasi.

Keikutsertaan peserta ke jenjang sertifikasi juga dikarenakan ada penugasan dari instansi untuk mengikuti sertifikasi tersebut. Hal ini menjawab mengapa respon peserta mengisi survey relatif rendah.

Persepsi bahwa program pelatihan yang dilakukan berhasil dan memiliki pengaruh yang signifikan dalam peningkatan kompetensi alumni berdampak kepada peningkatan budaya integritas organisasi sebagaimana ditunjukkan dalam tabel 4.7. Hal ini diperkuat dengan pernyataan yang disampaikan oleh atasan alumni dalam wawancara kepada atasan bahwa alumni telah beberapa kali menerapkan proses bagaimana memastikan bahwa di unit tempat kerja telah menerapkan prinsip-prinsip dari anti korupsi, di samping itu juga alumni telah menerapkan nilai-nilai anti korupsi dalam keseharian bekerja di unit kerja sehingga dapat menjadi contoh bagi pegawai lainnya.

Hasil - Evaluasi Kirkpatrick level 4, berhubungan dengan peningkatan produktivitas kerja. Produktivitas kerja yang dimaksud berkaitan dengan peningkatan integritas organisasi. Evaluasi ini dilakukan kepada alumni pelatihan tahun 2019. Evaluasi Level 4 dapat dilihat menurut jangka waktu pendek yaitu $1 / 2$ sampai 1 tahun setelah pelatihan dan menurut jangka panjang yaitu 2 sampai 10 tahun setelah pelatihan berakhir. Dalam kajian ini hasil yang dilihat masuk dalam jangka pendek yaitu 1 tahun.

Dalam waktu 1 tahun dapat dilihat hasil dari pelatihan. Sebagaimana dapat dilihat dalam hasil wawancara penulis kepada atasan. Disampaikan oleh atasan dalam wawancara bahwa alumni telah melakukan tindakan yang berdampak kepada efisiensi belanja yang dilakukan di instansi. Contohnya dalam proses pengadaan barang, alumni selalu memastikan efisiensi belanja dan melakukan konfirmasi langsung ke penyedia barang dan jasa. Yang dilakukan oleh alumni berdampak adanya pengurangan pemborosan dan ada peningkatan kualitas proses kerja. Hal ini dapat berjalan efektif karena alumni berhasil membangun tim yang berintegritas. Kesamaan persepsi dalam tim terkait integritas tidak terlepas dari upaya alumni memberikan pengarahan kepada para pegawai terkait dengan nilai-nilai antikorupsi.

Berkaitan dengan dengan kontribusinya bagi peningkatan budaya integritas, berdasarkan hasil wawancara dengan atasan dapat disampaikan sebagai berikut:

a.Budaya transparansi di instansi

Alumni telah memberikan kontribusi melalui pelaksanaan tugas menyajikan dan menyampaikan laporan sesuai data yang sebenarnya dan tepat waktu, dan memberikan ide/gagasan penyajian data secara transparan dalam pembahasan dana alokasi umum (DAU) saat pembahasan dengan DPR.

b.Budaya pelayanan yang bebas dari calo/perantara dan budaya bebas dari pertimbangan asal-usul /golongan (suku, agama, kekerabatan, almamater, dll) seseorang dalam pelaksanaan tugas/ pekerjaan.

Pada kedua aspek ini kontribusi alumni tidak terlihat, karena instansi di tempat alumni bekerja sudah tidak ditemukan lagi adanya praktik percaloan dan praktik diskirimatif dalam pelayanan maupun penugasan pegawai.

c.Budaya organisasi yang bebas dari penerimaan suap/gratifikasi (uang, barang, atau fasilitas)

Salah satu alumni dalam kapasitasnya sebagai Kepala Seksi Umum dan Kepatuhan Internal, telah menerapkan dan melakukan sosialisasi terkait pengelolaan gratifikasi di instansinya. Demikian juga alumni yang lain dalam bekerja telah menerapkan budaya antigratifikasi dan memberikan pemahaman kepada stakeholder yang ditemuainya ketika mereka hendak memberikan hadiah kepada pegawai tersebut dan timnya.

Sementara itu berhubungan dengan aspek peningkatan Sistem Integritas, yang tercermin dalam penerapan aktifitas sosialisasi antikorupsi dan sosialiasi sistem pencegahan korupsi, berdasarkan hasil wawancara dengan atasan langsung dapat disampaikan bahwa alumni telah melakukan kegiatan sosialisasi baik dalam kapasitas sebagai Pejabat Kepatuhan Internal maupun sebagai alumni pelatihan telah melakukan praktik penyuluhan kepada pegawai yang lain.

\section{KESIMPULAN}

Pelaksanaan pelatihan persiapan sertifikasi penyuluh antikorupsi memberikan perubahan perilaku peserta di tempat kerja. Hal dinyatakan dalam hasil survey ditunjukkan dengan hasil rata-rata sebelum pelatihan adalah 3,53 dan hasil rata-rata setelah pelatihan adalah 4,41 . Peningkatan perubahan perilaku ini dapat terjadi mengingat lingkungan pekerjaan yang dihadapi sehari-hari menuntut tanggung jawab dan perilaku integritas yang tinggi. Perubahan peningkatan perilaku yang ada pada alumni juga dikarenakan adanya peningkatan kompetensi alumni dalam bekerja.

Dari hasil wawancara diperoleh bahwa alumni dalam tugasnya sehari-hari di kantor juga telah menerapkan nilai-nilai dasar antikorupsi Perilaku ini dapat menguatkan posisi alumni sebagai Kasuki.

Keikutsertaan pegawai dalam pelatihan ini sesuai data pada tabel 4.4, sebanyak $\quad 77,8 \%$ menyatakan karena ditugaskan oleh instansi. Yang memang ingin mengikuti pelatihan hanya 22,2 \%. Secara data dapat diperoleh bahwa mengikuti pelatihan ini bukan karena keinginan pegawai tersebut. Dampak dari ini terlihat hampir 50\% peserta tidak berkenan untuk melanjutkan sampai ke jenjang sertifikasi.

Disampaikan oleh atasan dalam wawancara bahwa alumni telah melakukan tindakan yang berdampak kepada efisiensi belanja yang dilakukan di instansi. Disamping itu peserta memberikan 
kontribusi bagi peningkatan budaya integritas melalui kegiatan yang transparansi, tidak diskriminatif dalam pelayanan mendorong peningkatan Sistem Integritas melalui sosialisasi nilai-nilai integritas antikorupsi dan Sistem Pencegahan korupsi baik secara formal maupun non formal di tempat kerja.

Pelatihan Persiapan Sertifikasi Penyuluh antikorupsi perlu untuk terus dilaksanakan di masa mendatang mengingat kegiatan ini sejalan dengan program penguatan budaya integritas di lingkungan kementerian keuangan. Persyaratan peserta pelatihan diharapkan tidak saja berasal dari pejabat /pegawai yang memiliki keterkaitan tugas di unit kepatuhan internal, namun diperluas bagi pegawai yang memiliki minat dan ketertarikan dengan penegakkan integritas. Agar dapat membantu peserta dalam memenuhi persyaratan sertifikasi berupa pelaksanaan praktik penyuluhan di kantor maupun di lingkungan masyarakat, setelah pelaksanaan pelatihan klasikal/online, perlu dilanjutkan dengan pelaksanaan action learning untuk memberikan kesempatan peserta melakukan praktik penyuluhan dengan pendampingan dari para fasilitator. Salah satu hal yang dapat dilakukan dengan memberikan sosialisasi ke kantor-kantor pelayanan tentang budaya anti korupsi, pemberian brosur maupun flyer anti korupsi.

\section{References}

Arikunto, S. (2010). Prosedur Penelitian Suatu Pendekatan Praktik. . Jakarta: Rineka Cipta.

Arsyad, A. (2015). Media Pembelajaran. . Jakarta: PT.Raja Grafindo Persada .

Atmodiwirio, S. (2005). Manajemen Pelatihan. Jakarta: PT.Arda dizya Jaya.

Azwar. (2019). Implementasi Evaluasi Pascapembelajaran Model Kirkpatrick Lecel 1,2 dan 3 pada Pelatihan Bendahara Pengeluaran di
Balai Diklat Keuangan Makassar. Jogjakarta: Wiyata Dharma. Jurnal Penelitian dan Evaluasi Pendidikan.

Cresswell, J. W. (2010). Research Design. Pendekatan Kualitatif, Kuantitatif, dan Mixed. Edisi Ketiga. . Yogyakarta: Pustaka Pelajar.

Detty, R. (2009). Evaluasi efektivitas program pelatihan "Know Your Customer and Money Laundering" di Bank XYZ Bandung. Journal of Management and Bisnis Review, 20-34.

Kemenpan RB. (2018). Laporan Kinerja Kementerian Pendayagunaan Aparatur Negara dan Reformasi Birokrasi. Jakarta: Kemenpan RB.

Kementerian Keuangan. (2018). Laporan Kinerja Inspektorat Jenderal Kementerian Keuangan. Jakarta: Kementerian Keuangan.

Kirkpatrick, D. L. (2006). Evaluating Training Programs: The Four Levels (3rd edition). San Francisco, CA: Berrett-Koehler.

KPK. (2017). Laporan Ilmiah. Survey Penilaian Integritas. Jakarta: KPK.

Sekaran, U. (2006). Metodologi Penelitian untuk Bisnis, Edisi Ke Empat. Jakarta: Salemba Empat.

Wexley, K., \& Latham, G. P. (1991). Developing and Training Human Resources in Organization: Second Edition. New York: Harper Collins Publisher.

Widoyoko, S. E. (2009). Evaluasi Program Pembelajaran : Panduan Praktis Bagi Pendidik dan Calon Pendidik. Yogyakarta : Pustaka Pelajar. 